\title{
Nutritional Behavior and Status of Unaccompanied Minor Refugees in the Moria Camp, Lesbos, Greece
}

\author{
J. Bydzovsky (Jan Bydzovsky) 1, 2, 3, M. Jaclkulikova (Maria Jackulikova), 2, \\ S. Ousmann (Suliman Ousman)², R. Faashtol (Radwan Faashtol)²
}

${ }^{1}$ St. Elizabeth University of Healthcare and Social Work, Bratislava, Slovakia. Original Article ${ }^{2}$ NPHO SUPPORT MISSION Program, RIC Moria, Lesbos Island, Greece.

${ }^{3}$ Emergency Department, Hospital Ceske Budejovice, Czech Republic.

\section{E-mail address:}

bydzovsky@vszsp.cz

\section{Reprint address:}

Jan Bydzovsky

VSZaSP sv. Alzbety

Jiraskovy sady 240

26101 Pribram

Czech Republic

Source: Clinical Social Work and Health Intervention

Volume: 12

Issue: 2

Pages: $73-82$

Cited references: 16

\section{Reviewers:}

Dr. Johnson Nzau Mavole

Catholic University of Eastern Africa, Nairobi, KE

Zofia Szarota Pedagogical University of Cracow, PL

\section{Keywords:}

Nutritional Behavior. Unaccompanied and Separated Children. Refugees. Diet Program. Hygiene. Biological Needs. Psycho-social Needs.

\section{Publisher:}

International Society of Applied Preventive Medicine i-gap

CSWHI 2021; 12(2): 73 - 82; DOI: 10.22359/cswhi_12_2_14 (C) Clinical Social Work and Health Intervention

\section{Abstract:}

Greece faces a migration crisis caused by thousands of refugees coming from the Middle East and Africa to overwhelmed camps that try to fulfill at least their basic needs including diet as a humanitarian aid. The aim of the survey is to determine both the eating habits and possibilities and objective anthropometric parameters to evaluate the nutritional status of unaccompanied children under 18 years of age in the Moria refugee camp on the island of Lesbos, Greece. The survey has found that the respondents are completely dependent on the food provided by the camp. $87 \%$ of them reported starvation at least once a week, $24 \%$ are underweight. The energetic value of the provided food is insufficient as compared to their real needs. We have encountered serious complaints about the catering but 
have also found that more than half of the respondents state that they would be able to cook for themselves. These minor refugees are also at risk of starting with smoking cigarettes or drinking alcohol.

\section{Background}

The refugee crisis has been significantly affecting Europe since 2015. The mostly used form of their access to the European Union has been and still is a combination of land and sea routes, which are very risky for their lives. In 2016, approximately 362,000 refugees and migrants risked their lives by crossing the Mediterranean Sea, from whom around 173,450 people sailed to Greece as one of Europe's gateways.(2) In 2019, Europe recorded the entry of more than 123,663 refugees and migrants. There were at least 1,319 people missing or those who lost their lives when crossing the Mediterranean Sea. The migration was also affected by the Covid-19 pandemic in 2020. At the beginning of August 2020, the number of refugees and migrants arriving in Europe is estimated at 39,303.(3) High migration flows from Turkey to Greece during 2019 were also visibly reflected in the high number of unaccompanied minors. They were on their journey without family members or close relatives, putting themselves at high risk of various dangers including: violence; abuse and exploitation; uncertain access to food; drinking water; hygiene; health care. (5) Europe recorded the arrival of 33,200 children in 2019, of which 9,000 were unaccompanied and separated from their parents (unaccompanied and separated children, UASC). From January to December 2019, Greece records the number of arrivals by sea and land by 25,443 children, including 3,852 UASC, a huge increase in comparison with previous years. Most of them come from Afghanistan, Syria, Iraq or Congo.

Increased migratory movements were also proportionally reflected in the UASC standard of living, especially in reception and identification centers. In 2019, 2,781 UASC (more than half) remained out of suitable accommodation in Greece. The total number of UASC in Greece as of December 2019 is estimated at 3,852 children. Of these, 2,034 (42\%) were in suitable accommodation. Out of 3,852 UASC, $21 \%$ were aged 0-4 years and $79 \%$ of the UASC population accounted for aged 5-17 years. Overall, Europe has a predominance of boys over girls.(1)
The arrival of unaccompanied newly admitted children and children separated from their parents takes place in the first European contact countries. Children are usually accommodated in large accommodation centers and supervision is often minimal or totally absent. The situation of children on the Greek islands remains one of the most worrying. The camps are overcrowded, and the high population growth of UASC reception centers is difficult to cope with. Violence incident prevention and response (SGBV) is becoming increasingly challenging, especially in the islands of Lesbos and Samos, as well as in some mainland locations where UNHCR receives more reported incidents.

\section{Management of the Catering System in the Receiver, Registration and identification of the Moria Center on the Island of Lesbos}

UASC's health and mental health problems were not limited to poor housing conditions which were uncompromisingly complicated by the Covid-19 pandemic. The problems also concerned the lack of food and the quality of it that were criticized by most of the minors as well as adult refugees and migrants. Local staff and educators working directly in the sections for minors did not comment positively on the diet program in Moria refugee camp as well. It is true that it has been difficult to meet the unprecedented growing population of refugees and migrants in the First Income Center (KE.P.Y), also in the Registration and Identification Center (RIC) in Moria, Lesbos. As in similar centers, food was distributed in the form of catering and the Greek army was entrusted with the main responsibility for its provision. The following information on the functioning of the catering on Moria is drawn from the criteria of projects for which tenders were opened for those interested in providing catering services, published on the website of the Army General Staff (GES) of Greece. Several open offers for catering services in refugee centers, which were current in early 2020 , had the same criteria, the same budget and duration, and differed only in the date of imple- 
mentation, serial number and minor details.(6)

We describe the provision of food and catering services in Moria on the basis of a specific open offer of a contract for performing food preparation activities for refugees and migrants located in KE.PY also in RIC Moria, near the military camp "PARADELI" (hereinafter referred to as the camp / RIC Moria) on the island of Lesbos.(6) The contracting authority, appointed by the GES, was the 98th Battalion of the High Command of the National Guard of the DNSI Archipelago. Due to the exceptional crisis situation and the urgency of the needs, for RIC Moria, procurement for the catering service provider was carried out through a negotiated procedure without publication of a tender. Negotiation processes for the catering service provider and the acceptance of offers took place in early 2020 in several stages. The budget financed by the Army General Staff was 497,776 euros, including VAT, and covered the provision of catering services for a period of 4 days. In February and March 2020, it was a matter of providing food for 22,200 refugees and migrants living in the RIC Moria. Due to the specificity of the service provided and the fact that it was not possible to determine in advance the final number of daily meals, the catering provider unilaterally reserved the right to change the number of meals and thus the daily rations, in accordance with the procedure set out in the procurement document.

The daily distribution of ready meals in Moria camp could be in the maximum price of 5.46 euros, including 9\% VAT (5.01 euros without VAT) per person per day. According to the criteria stated in the document of the tender for the procurement of catering services, the all-day meal was divided into breakfast, lunch and dinner with the possibility of adding food. It also included a drinking regime and special meals for vulnerable groups of refugees and migrants. The special diet was divided into meals for diabetics, pregnant women, breastfeeding mothers and children. Children's meals were differentiated according to age categories 0-6 months, 6-12 months, 1-12 years. For the remaining population of asylum seekers, this was a common diet, which was also provided to UASC over the age of 12 .

According to the criteria in the procurement of catering services, the daily energy value of food in the regular diet for persons older than 12 years was approximately 2,000 calories $( \pm 100$ kcal) per person; in diabetics 1,800 calories $( \pm$ $100 \mathrm{kcal})$ per person; in children from 1 to 12 years 2,400 calories $( \pm 100 \mathrm{kcal})$; in children from 6 to 12 months, 2,300 calories $( \pm 100 \mathrm{kcal})$ per day; children under 6 months were given baby milk powder if their mothers were unable to breastfeed for various reasons. Each person, regardless of age, i.e. from 0 months onwards, was entitled to drinking water for a total of 2.5 liters of bottled water per person per day.

Candidates for the provision of catering services had to meet the qualification requirements, the place for food preparation can be checked by the hygienic inspection service. The products they planned to use for the production of food, transport, packaging and storage of food products were to comply with the Food Code and the hygiene rules defined in the Food and Beverages Act. The quality of the meals offered should be in accordance with the Food Code. The competent food service providers at the RIC Moria were required to take food samples and, if requested, provide them for analysis two to three times a month.

Portions of food were brought directly to the recipients in the Moria camp to be served at a temperature suitable for eating and in disposable containers, using disposable cutlery, cups and napkins. The criteria state the issuance of food at breakfast time: from 7:00 to 9:00, lunch time: from $12: 30$ to $14: 30$ and dinner time from 19:00 to 21:00 in the form of a self-service system with strict adherence to hygiene rules. The criteria also underline the fact that the catering service provider at the RIC Moria undertakes not to use products or processes that the Muslim religion does not allow (pork, alcohol) to prepare meals.

Fresh and seasonally available fruits and vegetables should be properly cleaned, served as often and as fresh as possible (salads, fresh and whole cucumbers, tomatoes, onions and all vegetables covered by meal plans). The distribution of fruit was to include bananas, apples, grapes, peaches, plums, oranges, cherries, melons to ensure diversity.

Meat, vegetable sauces and side dishes should be served individually, e.g. "Spaghetti with sauce" means spaghetti and sauce distrib- 
uted in separate packages. Pasta, rice and other starches should be adequately cooked and, as required by the specific recipe, served separately so that they can be mixed. The meat should have been well cooked, not raw. The supplier had to be checked whether the beef contained any pork or products from it.

The diet (menu) was to be changed at least every month to ensure nutritional diversity (with a change in products of the same category, e.g. change of legumes, alternation of pasta, tea with juice, etc.) and importance was placed on maintaining proper consumption and food expiration. [6]
The calculated energetic value of this example corresponds to 2,000 kcal daily as declared in the document. Examples of meals are shown in the following photographs in Fig. 1.

The criteria for selecting candidates for catering services in the RIC Moria correspond to the reality of catering for people living in a refugee camp very little. Due to the crisis situation, the selection of contractors took place without a public tender. The competent people state that selection processes were carried out in accordance with principles such as transparency, non-discrimination and ethics. Ethical behavior presents the economical use of resources, unjust enrich-

Tab. 1 Example of menu for persons aged 12 and up.

\begin{tabular}{|c|c|c|c|c|}
\hline Day & Breakfast & Lunch & Diner & Remarks \\
\hline Monday & $\begin{array}{l}\text { tea, croissant } 75-80 \mathrm{~g}, \\
\text { seasonal fruit } 1 \mathrm{pc}\end{array}$ & $\begin{array}{l}\text { pasta } 250 \mathrm{~g} \text { with } \\
\text { tomato sauce, } \\
\text { feta cheese } 50 \mathrm{~g}\end{array}$ & \begin{tabular}{|l|} 
omelet (3 eggs), \\
potatoes $150 \mathrm{~g}$, \\
seasonal fruit $1 \mathrm{pc}$
\end{tabular} & \multirow{7}{*}{$\begin{array}{l}\text { 1. for lunch and } \\
\text { dinner, } 2 \text { pieces } \\
\text { of Arabic bread } \\
60-70 \mathrm{~g} / \mathrm{pc} \text { are } \\
\text { added to each } \\
\text { portion } \\
\text { 2. seasonal fruit } \\
\text { should have } 100 \text { - } \\
120 \text { g per serving } \\
\text { 3. all quantities } \\
\text { refer to ready-to- } \\
\text { eat meals ready } \\
\text { for consumption } \\
\text { 4. daily diet con- } \\
\text { tains } 2,000 \\
\text { ( } \pm 100) \text { kilocalo- } \\
\text { ries per person } \\
\text { 5. each meal in- } \\
\text { cludes } 2.5 \text { liters } \\
\text { of bottled water } \\
\text { per person to } \\
\text { cover daily needs }\end{array}$} \\
\hline Tuesday & $\begin{array}{l}\text { juice, Arabic bread 60- } \\
70 \mathrm{~g} \text {, seasonal fruit } 1 \mathrm{pc}\end{array}$ & $\begin{array}{l}\text { lentils } 300 \mathrm{~g} \text {, feta } \\
\text { cheese } 50 \mathrm{~g}\end{array}$ & \begin{tabular}{|l|} 
peas with pota- \\
toes $300 \mathrm{~g}$, feta \\
cheese $50 \mathrm{~g}$, \\
seasonal fruit $1 \mathrm{pc}$
\end{tabular} & \\
\hline Wednesday & $\begin{array}{l}\text { tea, fresh artichokes } \\
100 \mathrm{~g} \text {, seasonal fruit } \\
1 \mathrm{pc}\end{array}$ & $\begin{array}{l}\text { stewed chicken } \\
250-300 \mathrm{~g} \text {, rice } \\
100 \mathrm{~g}\end{array}$ & $\begin{array}{l}\text { pasta } 250 \mathrm{~g} \text { with } \\
\text { tomato sauce, } \\
\text { feta cheese } 50 \mathrm{~g}, \\
\text { seasonal fruit } 1 \mathrm{pc}\end{array}$ & \\
\hline Thursday & $\begin{array}{l}\text { juice, Arabic bread 60- } \\
70 \text { g, seasonal fruit } 1 \mathrm{pc}\end{array}$ & \begin{tabular}{|l|} 
mashed potatoes \\
$300 \mathrm{~g}$ with \\
tomato sauce, \\
seasonal fruit $1 \mathrm{pc}$
\end{tabular} & $\begin{array}{l}\text { omelet (3 eggs) } \\
\text { with potatoes } \\
150 \text { g,seasonal } \\
\text { fruit } 1 \mathrm{pc}\end{array}$ & \\
\hline Friday & $\begin{array}{l}\text { tea, fresh artichokes } \\
100 \mathrm{~g} \text {, seasonal fruit } \\
1 \mathrm{pc}\end{array}$ & $\begin{array}{l}\text { oil beans with } \\
\text { potatoes } 300 \mathrm{~g}, \\
\text { feta cheese } 50 \mathrm{~g}\end{array}$ & \begin{tabular}{|l|} 
roasted potatoes \\
$250 \mathrm{~g}$, feta cheese \\
$50 \mathrm{~g}$, seasonal \\
fruit $1 \mathrm{pc}$
\end{tabular} & \\
\hline Saturday & $\begin{array}{l}\text { juice, Arabic bread 60- } \\
70 \text { g, seasonal fruit } 1 \text { pc }\end{array}$ & $\begin{array}{l}\text { bean soup } 300 \mathrm{~g}, \\
\text { olives }\end{array}$ & \begin{tabular}{|l|} 
rice $250 \mathrm{~g}$ \\
with tomato \\
sauce, feta cheese, \\
seasonal fruit $1 \mathrm{pc}$
\end{tabular} & \\
\hline Sunday & $\begin{array}{l}\text { tea, fresh artichokes } \\
100 \mathrm{~g} \text {, seasonal fruit } \\
1 \mathrm{pc}\end{array}$ & $\begin{array}{l}\text { beef } 150 \mathrm{~g} \text {, pasta } \\
250 \mathrm{~g}\end{array}$ & $\begin{array}{l}\text { roasted potatoes } \\
250 \mathrm{~g} \text {, feta cheese } \\
50 \mathrm{~g} \text {, seasonal } \\
\text { fruit } 1 \mathrm{pc}\end{array}$ & \\
\hline
\end{tabular}


Fig. 1 Examples of meals (catering) provided for lunches and dinners in the Moria camp

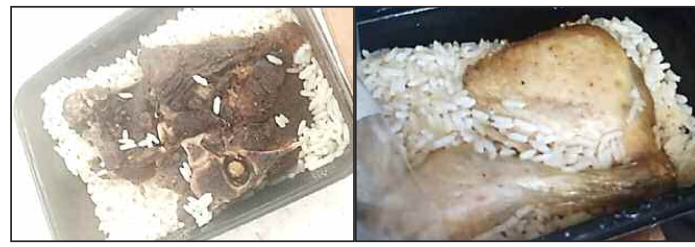

ment, non-corruption, bribery and family nepotism.(6)

Nutrition is a primary biological need and an important prerequisite for sustaining life. An adequate diet contains a balanced amount of essential nutrients. Foods differ in their nutritional value and no food provides all the essential nutrients. Improper supply of nutrients common in emergencies: reduces immunity; increases morbidity; exacerbates chronic health problems; causes anemia; sleep disorders; dermatological problems; poor wound healing; delays in mental and physical development in children; affects the body's balance.(7)

The actual level of catering provision in the RIC Moria together with the unsuitable housing conditions confirm the severity of social suffering at UASC. Nutrition and food intake not only satisfies the body's digestive system and energy reserves. Food intake, like other human biological needs, is associated with psycho-social needs and positive emotions. Long-term non-satisfaction of food needs becomes a dominant problem and controls the whole human behavior.(7)

The UASC and thousands of people living in the indecent conditions of the Moria refugee camp have long: decried their frustration, dissatisfaction with the slow asylum process; housing; food; other determinants of social suffering. The Covid-19 pandemic and subsequent strict quarantine measures joined the complicated solution to their fates. This combination proved to be explosive, resulting in protests against pandemic measures and the subsequent burning of the Moria refugee camp. [8]

\section{The End of Moria Camp}

Unfortunately, the Moria refugee camp does not exist anymore. It had been burnt down even before the results of our research were published. RIC Moria was set on fire on Tuesday night from 8th to 9th September 2020. The arsonists repeatedly set fire to the camp for 3 days. On Thursday

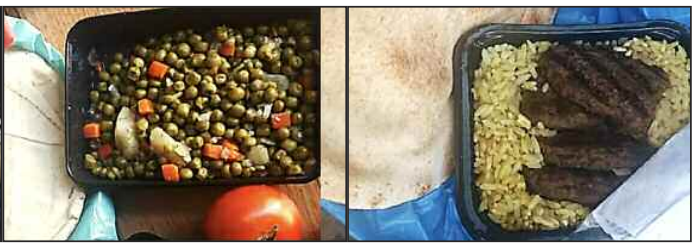

afternoon, 10th September 2020, a third fire broke out in Moria, destroying the little that was still untouched by the fire. 12,000 people became homeless in the wilderness, located between tombstones in a nearby cemetery and on country and coastal roads. As it turned out, 6 young men of Afghan descent were convicted. The quartet is 19-20 years old. The two most active were 17year-old minors who were arrested according to the arrest warrant issued by the Mytilene Prosecutor's Office in Katerini and Thessaloniki, where they were taken to safety with another 204 UASC after the complete destruction of the Moria camp. Humanitarian aid workers, activists and officials said the series of fires was deliberately started by a group of camp residents who were furious at being forced into quarantine after at least 35 people had tested positive for SARS$\mathrm{CoV}-2$ in the Moria camp. Arsonists, including two 17-year-old UASC were convicted of turning the largest refugee camp in Europe to ashes within 3 days. [9]

\section{Methods}

63 out of estimated total number 394 minor unaccompanied refugees (i.e.16\%) have been assessed for their nutritional condition as a part of a basic health care the respondents sought for at the outpatient clinic run by St. Elizabeth University of Healthcare and Social Work in Bratislava and Health Point Foundation. All of them were boys aged 12 to $17(15.7 \pm 0.9)$ from Afghanistan (59, i.e. 94\%), Syria (2), Togo (1) and Kuwait (1). 23 of them were settled in Section A, 21 in Section B, 1 in the Safe zone and 18 lived in the „Jungle“.

The assessment started by obtaining the informed consent; measurements and calculations of: weight; height; waist (halfway between the lowest rib and the top of the hipbone); hip (the largest circumference around the hip); mid-upper arm circumference; and body fat measured by advanced scales using the bio-impedance method. Eating habits were determined using a question- 
naire translated to their mother tongue by the interpreters. The whole screening took approximately 10 minutes for each respondent.

\section{Results}

The results are presented as means \pm SEM (standard error of the mean). The average length of stay in the Moria camp was $8.8 \pm 2.3$ months (from 1 to 18). The heights of the respondents were from 158 to $186 \mathrm{~cm}$, on average $171.8 \pm 5.6 \mathrm{~cm}$. The weights were from 38.5 to 90.8 , on average $60.6 \pm 9.3 \mathrm{~kg}$. Calculated body mass indexes (BMI) were from 13.6 to $28.0 \mathrm{~kg} \cdot \mathrm{m}^{-2}$, on average $20.5 \pm 2.8 \mathrm{~kg} \cdot \mathrm{m}^{-2} .15(24 \%)$ of them had BMI lower than $18.5 \mathrm{~kg} \cdot \mathrm{m}^{-2}$. Out of these 15 respondents only 3 came from the „Jungle“ (where they can have worse access to the food), also the length of the stay in the camp of these 15 respondents was $8.9 \pm 1.1$ months, i.e. similar to the whole group. Three respondents $(4,7 \%)$ had their BMI in the zone of severe thinness, i.e. $<16.0 \mathrm{~kg} \cdot \mathrm{m}^{-2}$.(15) [15] Situation where the acute malnutrition rate is $15 \%$ or more or is $10-14 \%$ with aggravating factors, i.e. energetic value below the mean energy requirements, high prevalence of respiratory or diarrheal diseases etc., is considered to be a serious nutritional emergency by UNHCR. [14]

Three $(4.8 \%)$ out of the respondents had BMI in the range of overweight, i.e. $25.1-30.0 \mathrm{~kg} \cdot \mathrm{m}^{-2}$. It is interesting that the number of corresponds, even in this small sample, to the reported prevalence of obesity in Afghanistan that was $3.2 \%$ in 2016 for male population aged $18+$ and prevalence of overweight males under 5 years that was reported $4.0 \%$ in 2018, according to the World Bank collection of development indicators.

The correlation of BMI with the length of the stay was -0.04 (i.e. they are obviously not losing their weight as they stay in the camp for a longer time). Beside the BMI other means of assessing the amount of body fat were used(7):

1. measurements of waist and hip circumference and WHR (waist-hip ratio): the waist circumference was $73.7 \pm 5.4 \mathrm{~cm}$, the hip circumference $94.8 \pm 4.8 \mathrm{~cm}$, the values of WHR were from 0.73 to $0.89(0.78 \pm 0.03)$.

2. measurements of mid-upper arm circumference taken on non-dominant upper limb: the values were from 22.5 to $33.0(26.0 \pm 2.4) \mathrm{cm}$.

3. bio-impedance analysis of body fat $(\mathrm{BF} \%)$ : the values were from 5.0 to $25.3(12.7 \pm 5.4 \%)$ percent. Normal range for males under 40 years is 8 to $20 \%$.

Correlation of these parameters with BMI was: 0.17 for WHR 0.42 for mid-upper arm circumference; 0.50 for waist circumference; 0.96 for $\mathrm{BF} \%$ from bio-impedance analysis showing almost perfect correlation of these two indicators. Poor correlation of WHR and $\mathrm{BF} \%$ has been found as in other researches.(11)

Generally, the daily requirements could be estimated as $25-35 \mathrm{kcal} / \mathrm{kg}$ of energy and $30 \mathrm{ml} / \mathrm{kg}$ of fluids in adults.(14) The basal metabolic rate (BMR) calculated using the Harris-Benedict formula (for males: $66+13.7 \times$ weight $+5 \times$ height $6.8 \times a g e)$ was from 1,318 to $2,101 \mathrm{kcal}$ per day, on average 1,649 $\pm 143 \mathrm{kcal}$ (median 1,641 kcal). Taking into account that the Harris-Benedict formula is sometimes believed to overestimate the metabolic needs, the Mifflin-St. Jeor formula (for males: $10 \times$ weight $+6.25 \times$ height $-5 \times$ age +5 ) being reported as better correlating to indirect calorimetry measurements or more accurate for overweight persons(12) was also used with results ranging from 1,355 to $1,958 \mathrm{kcal}$ per day, on average 1,607 $\pm 113 \mathrm{kcal}$ (median 1,610 kcal). To estimate the daily energetic expenditures the BMR is multiplied by an activity factor that depends on the physical activity. Daily routine of these UASC comprises attending school in the city of Mytilene where they used to be taken by buses in the morning and leisure activities like playing football, ping-pong or going swimming in the sea that were organized by different NGO's in the afternoon. We count these activities with at least light or possibly moderate ones, i.e. activity factor 1.375-1.550. An example of a daily routine comprising: 8 hours of sleep; 1 hour walking with a load; 2 hours of sitting tasks; 2.5 hours of sedentary recreation; 2.5 hours of walking around; 8 hours of sitting quietly gives weighted activity factor 1.53 for men.(13)

Moreover, the result should be multiplied by injury factor in case of ongoing injury or illness (1.30-1.55 for severe infection), healing wounds (1.2-1.6). The energetic expenditures become higher in case of: stress; cold weather (100 kcal daily for every $5{ }^{\circ} \mathrm{C}$ below $20{ }^{\circ} \mathrm{C}$ ); insufficient clothing; etc. Up to $20 \%$ must be added for every $1{ }^{\circ} \mathrm{C}$ of fever. $(13,7,12,15)$ Calculated energetic demands for respondents in our sample are shown in the tables 2 a 3 below: 
Tab. 2 Calculated energetic demands of the respondents according to the Harris-Benedict equation.

\begin{tabular}{|l|l|l|l|l|l|l|}
\hline Activities & $\begin{array}{l}\text { activity } \\
\text { factor }\end{array}$ & $\begin{array}{l}\text { minimum } \\
\text { energy } \\
\text { (kcal) }\end{array}$ & $\begin{array}{l}\text { maximum } \\
\text { energy } \\
\text { (kcal) }\end{array}$ & $\begin{array}{l}\text { average } \\
\text { energy } \\
\text { (kcal) }\end{array}$ & $\begin{array}{l}\text { median } \\
\text { energy } \\
\text { (kcal) }\end{array}$ & $\begin{array}{l}\text { need } \\
\text { 2000 kcal } \\
\text { (out of 63) }\end{array}$ \\
\hline None (BMR) & 1.000 & 1,318 & 2,101 & 1,649 & 1,641 & $1(2 \%)$ \\
\hline $\begin{array}{l}\text { Sedentary } \\
\text { (no or little } \\
\text { exercise) }\end{array}$ & 1.200 & 1,582 & 2,521 & 1,979 & 1,970 & $27(43 \%)$ \\
\hline $\begin{array}{l}\text { Light } \\
\text { (sports 1-3 } \\
\text { days/week) }\end{array}$ & 1.375 & 1,812 & 2,889 & 2,267 & 2,256 & $58(92 \%)$ \\
\hline $\begin{array}{l}\text { Moderate } \\
\text { (sports 3-5 } \\
\text { days/week) }\end{array}$ & 1.550 & 2,043 & 3,257 & 2,556 & 2,544 & $63(100 \%)$ \\
\hline
\end{tabular}

Tab. 3 Calculated energetic demands of the respondents according to the Mifflin-St. Jeor equation.

\begin{tabular}{|l|l|l|l|l|l|l|}
\hline Activities & $\begin{array}{l}\text { activity } \\
\text { factor }\end{array}$ & $\begin{array}{l}\text { minimum } \\
\text { energy } \\
\text { (kcal) }\end{array}$ & $\begin{array}{l}\text { maximum } \\
\text { energy } \\
\text { (kcal) }\end{array}$ & $\begin{array}{l}\text { average } \\
\text { energy } \\
\text { (kcal) }\end{array}$ & $\begin{array}{l}\text { median } \\
\text { energy } \\
\text { (kcal) }\end{array}$ & $\begin{array}{l}\text { need } \\
\text { >2000 kcal } \\
\text { (out of 63) }\end{array}$ \\
\hline None (BMR) & 1.000 & 1,355 & 1,958 & 1,607 & 1,609 & $0(0 \%)$ \\
\hline $\begin{array}{l}\text { Sedentary } \\
\text { (no or little } \\
\text { exercise) }\end{array}$ & 1.200 & 1,626 & 2,350 & 1,928 & 1,931 & $18(29 \%)$ \\
\hline $\begin{array}{l}\text { Light } \\
\text { (sports 1-3 } \\
\text { days/week) }\end{array}$ & 1.375 & 1,863 & 2,692 & 2,210 & 2,212 & $57(90 \%)$ \\
\hline $\begin{array}{l}\text { Moderate } \\
\text { (sports 3-5 } \\
\text { days/week) }\end{array}$ & 1.550 & 2,100 & 3,035 & 2,491 & 2,494 & $63(100 \%)$ \\
\hline
\end{tabular}

The energetic value of the supplied food during the day for such minors reliably covers their basal metabolic needs only, therefore should be higher than 2,000 kcal, roughly around at least 2,300-2,500 kcal to prevent malnutrition, in some it could be up to $3,000 \mathrm{kcal}$. It is important to notice that there is a great difference in the energetic needs where the highest value is about $60 \%$ higher than the lowest one, therefore the portions should also take in account the age, stature, etc. Prior to 1989 the daily amount of 1,500 kcal was used and then 1,900 kcal until 1993. At present, the World Health Organization and UNHCR as well recommend 2,100 kcal per capita for initial planning for standard population and light activ- ities in a developing country before more accurate calculations are carried out. An additional ration of 100-200 kcal should be provided if the health or nutritional status of the population is poor. At least $10 \%$ of the energy should be provided in the form of protein and $17 \%$ of the energy in the form of fat. $(13,15)$

The respondents were asked about their eating habits and frequency of having meals (breakfast, lunch, dinner and snacks - each was considered as one meal) and specific food using a semi-quantitative scale from: never ( 0 days a week); few days (approximately 2 days a week); most days (approximately 5 days a week) to daily (7 days a week). Besides the pro- 
vided diet they were occasionally given some snacks from NGO's and private donors.

The respondents reported having from 4 to 28 meals per week, on average $19.0 \pm 7.0$ (18.4 in the Sections and Safe zone and 16.7 in the ,Jungle“, $p=0.20$ for one-sided t-test). The approximate numbers of meals per week were 3.7 for breakfast, 5.4 for lunch, 5.2 for dinner and 3.6 for snacks. They commented in their answers that they don't have meals regularly because the food from the catering is often not eatable. Given examples of typical foodstuff for the meals are shown in the table below.

\section{Tab. 3 Examples of typical foodstuff the respondents were provided with}

\begin{tabular}{|l|l|l|l|}
\hline breakfast & lunch & dinner & Snacks \\
\hline bread & bread & bread & nuts \\
cheese & cheese & cheese & orange \\
honey & fish & honey & bread \\
müsli & rice & eggs & yogurt \\
tomato & spaghetti & müsli & raisins \\
sesame- & macaroni & tomato & chips \\
cream & chicken & macaroni & biscuits \\
milk & beans & rice & dried fruit \\
orange & potatoes & lamb & tomato \\
tea & vegetable & chicken & peach \\
yogurt & nuts & meatballss & chocolate \\
eggs & meatballs & sandwich & banana \\
banana & lamb & fish & \\
sandwich & sandwich & potatoes & \\
peach & sausage & nuts & sesame \\
jam & & cream & \\
& & orange & tea \\
& &
\end{tabular}

The correlation of BMI and the approximate number of meals per week was, surprisingly, 0.26 , i.e. weak negative dependence.

The respondents had at least one hot meal: approximately $1.6 \pm 2.6$ days a week for all; 1.2 \pm 2.4 days for the Sections and Safe zone; $2.6 \pm$ 2.7 days a week for the „Jungle“ ( $p=0.23$ for one-sided t-test). Many of the respondents commented that the cooked meals usually get cold before they are being dispensed.

The respondents had meat: approximately $2.0 \pm 0.8$ days a week; dairy products (milk, cheese, yogurt etc.) $3.1 \pm 2.5$ days a week; fruit or vegetables $4.7 \pm 2.6$ days a week; sweets 0.7 \pm 1.7 days a week. These frequencies also did not correlate with BMI: $r=0.04$ for meat; 0.02 for dairy products: 0.26 for fruit and vegetables; 0.18 for sweets.
Three of the respondents (5\%) reported drinking alcohol: one daily; two of them a few days a week. One started with it before coming to the camp, the two others in the camp. 21 (33 $\%$ ) of the respondents reported smoking cigarettes: 9 of them daily ( $43 \%$ of smokers, $14 \%$ of all). Six of them (28\%) started smoking before coming to the camp; the others (71\% of smokers, $10 \%$ of all) in the camp.

The respondents reported that they are feeling hungry $4.4 \pm 3.0$ days a week; $55(87 \%)$ at least once a week; 34 (54\%) daily. Only 8 are never starving (5 of these were from the "Jungle“). Most of the respondents complained about the very bad quality of the provided food that they found not well cooked (meat is bloody and they have to cook it again), expired (cheese) or even smelly, milk was suspected to be diluted with water, etc. Some reported stomach aches or feelings like vomiting after eating the food they were provided. The reasons that caused the profound differences between the planning of the quality of catering services and the reality in the RIC Moria were not the subject of an examination of our research.

The tap water in the camp is suitable for washing etc. but is not drinkable. The respondents were supplied with non-carbonated drinking water originally bottled in 1.5-liter bottles. Their access to bottled water is not restricted in any way; they are given new bottles when returning the empty ones. They estimate drinking 0.75 to 10 (!) liters of water per day, on average $2.3 \pm$ 1.5 (median 2.0) liters. The percentage of total body water as measured by bio-impedance method was from 53.2 to 70.0 ; on average 59.0 $\pm 3.1 \%$. The optimal range for males is 50 to $65 \%$, up to $5 \%$ more for athletic somatotypes. The correlation of estimated intake and percentage of total body water was -0.22 .

None of the respondents received any from the camp or Greek government etc. to buy extra food, only one reported that gets about 20 EUR per month, half of that he spends for food. Some reported being given food by the shopkeepers or cigarettes and alcohol by adult friends for free.

The respondents were also asked about their cooking skills: 23 (37\%) answered that they can cook; $16(25 \%)$ a bit - some simple meals; 24 $(38 \%)$ cannot cook at all.

Finally, the respondents were asked about 
their favorite meal and time they had it for the last time. They were not much demanding: pizza; kebab; chicken sandwich; hamburger; typical Afghan meals like Kabuli pulao (rice with meat and carrot); Biryani (rice, meat, spices); Shorwa (meat soup); but also fried vegetables; eggplant; beans. 15 of the respondents (24\%) reported having their favorite meal a year or more ago.

\section{Conclusions}

The BMI was found as a best simple predictor for body fat percentage measured by the bio-impedance method. About a quarter of unaccompanied minor refugees in the Moria camp have their $\mathrm{BMI}$ in the range of underweight. This number is independent of the length of stay in the camp. To prevent malnutrition, the energetic value of the provided food should be at least $15-25 \%$ higher than 2,000 kcal daily; roughly around at least $2,400 \mathrm{kcal}$ but for some up to $50 \%$ higher; around $3,000 \mathrm{kcal}$, depending on the age and stature. Nutrition screening and evaluation of real needs should be carried out on admission to the camp. Those at risk (ill and injured, with chronic wounds) or already in malnutrition should be provided with extra rations or nutrition supplements like protein bars, biscuits and ready-to-use therapeutic food. Having no money, the respondents are completely reliant on provided food. They reported starvation for approximately 4.4 days of week, $87 \%$ are feeling hungry at least once a week, but also problems with freshness and cooking procedures of the provided food that lead to even not eating the provided meal at all. These are alarming problems where further investigation and finding solutions are needed. Possibly the fact that more than a half are able to cook could help. One tenth of the respondents started smoking cigarettes after coming to the camp, therefore education about the risks of smoking is desirable. We have not found problems with access to drinking water nor worse nutrition screening outcomes of the minors living in the „Jungle“ in comparison with those living in the Sections and the Safe zone, i.e. with better and guaranteed access to catering. In such facilities we advise regular quality controls (at least of the amount and sensoric parameters: look; smell; temperature; taste) of the food provided by the catering company and evaluation surveys for the boarders, possibly also experiments with providing them with raw and semi-finished food and letting them cook for themselves under supervision of their guardians in a community kitchen.

Author Contributions: contributors in the preparation of this manuscript are as follows: Bydzovsky, J. 45\%, Jackulikova, M. 40\%, Suliman, O. $10 \%$, Faashtol, R. 5\%. Our special thanks belong to Ms. Parwin Said, the translator, without whom it would be impossible to carry out this research.

Funding: This research received no external funding.

Conflicts of Interest: The authors report no conflicts of interest.

\section{References}

1. UNITED NATIONS HIGH COMMISSIONER FOR REFUGEES (UNHCR) (2020) Figures at a Glance. [(accessed on 18 July 2020)]; Available online: https://www. unhcr.org/figures-at-a-glance.html.

2. UNITED NATIONS HIGH COMMISSIONER FOR REFUGEES (UNHCR) (2020)Europe situation. [(accessed on $8 \mathrm{Au}-$ gust 2020)]; Available online: https://www. unhcr.org/europe-emergency.html.

3. UNITED NATIONS HIGH COMMISSIONER FOR REFUGEES (UNHCR) (2020) Figures at a Glance. [(accessed on 8 August 2020)]; Available online: https:// data2.unhcr.org/en/situations/mediterranean.

4. INTERNATIONAL ORGANIZATION FOR MIGRATION (IOM) (2020) Fatal journeys volume 4: Missing migrant children. [(accessed on 6 August 2020)]; Available online: https://publications.iom.int/system/files/pdf/fatal_journeys_4.pdf.

5. WOMEN'S REFUGEE COMMISSION (WRC) (2020) More Than One Million Pains: Sexual Violence Against Men and Boys on the Central Mediterranean Route to Italy. [(accessed on 18 July 2020)]; Available online: https://www.womensrefugeecommission.org/research-resources/more-thanone-million-pains-sexual-violence-againstmen-and-boys-on-the-central-mediterranean-route-to-italy.

6. STRATOU G E(GES) (2020) Enimerosi/ Pomithies [(accessed on 29. August 2020)]; 
Available online: http://www.army.gr/el/enimerosi/promitheies.

7. WORLD HEALTH ORGANIZATION (WHO) (2000) The Management of nutrition in major emergencies. (accessed on 18 September 2020). Available online: https://apps. who.int/iris/handle/10665/42085.

8. GLOBAL DETENTION PROJECT (2020) Greece. In: COVID 19 Platform. (accessed on 22 December 2020)]; Available online: https://www.globaldetentionproject.org/coun tries/europe/greece.

9. KINGLEY P (2020) Fire Destroys Most of Europe's Largest Refugee Camp, on Greek Island of Lesbos. In: The New York Times [(accessed on 30.September 2020)]; Available online: https://www.nytimes.com/2020/ 09/09/world/europe/fire-refugee-camp-lesbos-moria.html.

10. EUROPEAN UNION (2020) 29 April 2004 - Regulation (EC) 852/2004 on the hygiene of foodstuffs. In: Legislation.[(accessed on 28.September 2020)]; Available online: https://ec.europa.eu/food/safety/biosafety/fo od_hygiene/legislation_en.

11. OSAYANDE O E, AZEKHUMEN G N, OBUZOR E O (2018) A Comparative Study of Different Body Fat Measuring Instruments. Niger. J. Physiol. Sci. 33 December 125-128.

12. PILAND C, ADAMS K (Eds.) (2009)Pocket Resource for Nutrition Assessment: 2009 Edition. 7th ed. Texas: American Dietetic Association, 2009. P 129 https://dpg-storage.s3 .amazonaws.com/dhcc/resources/Pock etResources/PRNA\%202009.pdf.

13. INSTITUTE OF MEDICINE (US) (1995) Committee on International Nutrition; Allen LH, Howson CP, editors. Estimated Mean per Capita Energy Requirements for Planning Emergency Food Aid Rations. Washington (DC): National Academies Press (US); 1995. 2, Estimating Energy Requirements of Refugee and Other Populations Requiring Food Aid. Available from: https://www.ncbi.nlm.nih.gov/books/NBK2 31163/.

14. UNITED NATIONS HIGH COMMISSIONER FOR REFUGEES (UNHCR) (2007) Handbook for Emergencies. 2007. 3rd Ed. Geneva: UNHCR.
15. CLUGSTON G A Food and Nutrition Needs in Emergencies. Geneva: UNHCR.

16. GEZAIRY H, FIELD A (1995) Guide on Rapid Nutritional Assessment in Emergencies. Alexandria: WHO, Regional Office for the Eastern Mediterranean, p 63. ISBN 929021-234-9. 